\title{
Rh-Catalyzed Asymmetric Addition of Trifluoroborates to Sulfonylketimines
}

Metal-Mediated Synthesis

\section{Key words}

rhodium

asymmetric synthesis

trifluoroborates

ketimines

\section{SYNFACTuth}

Selected examples:<smiles>CC(NF)(c1ccccc1)c1ccc(Cl)cc1</smiles>

$98 \%$ ee $84 \%$ yield<smiles>[NH-]N[C@]1(c2ccccc2)CCOc2ccccc21</smiles>

$99 \%$ ee $88 \%$ yield<smiles>C[C@](NN[S+](=O)[O-])(c1ccccc1)c1ccco1</smiles>

$95 \%$ ee $71 \%$ yield
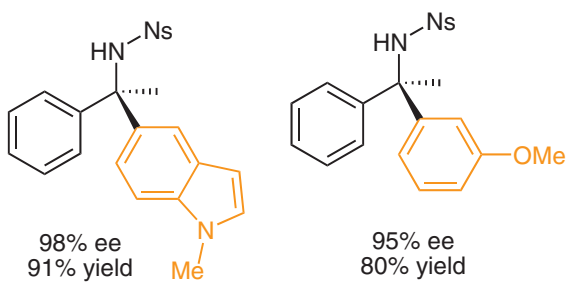

$95 \%$ ee $80 \%$ yield

Typical deprotection of the addition products:<smiles>C[C@](NN[N+](=O)[O-])(c1ccccc1)c1ccc(Cl)cc1</smiles>

$95 \%$ ee

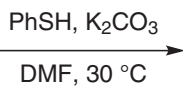

$\mathrm{Cl}$<smiles>NC(c1ccccc1)c1ccc(Cl)cc1</smiles>

$95 \%$ ee $89 \%$ yield
Significance: Easily accessible potassium organotrifluoroborates undergo a rhodium-catalyzed asymmetric addition to both $N$-tosyl and $N$-nosyl ketimines. The use of a chiral bicyclooctadienebased ligand allows high enantiomeric excess in the product formation.
Comment: In the case of nosyl groups, the addition products can easily be deprotected using thiophenolpotassium carbonate, retaining the enantiomeric purity. For related applications of dienic ligands, see: K. Okamoto, T. Hayashi, V. H. Rawal Org. Lett. 2008, 10, 4387. 